\title{
THE INFLUENCE OF KNOWLEDGE AND DISASTER WARNING AND THE PREPARATION OF HIGH SCHOOL STUDENTS IN FACING EARTHQUAKE AND TSUNAMI
}

\author{
Ruri Maiseptya Sari ${ }^{*}$, Hanifah Hanifah ${ }^{2}$, Vike Pebri Giena ${ }^{2}$ \\ ${ }^{1}$ Diploma IV Program STIKES Tri Mandiri Sakti, Bengkulu \\ ${ }^{2}$ Nursing Study Program STIKES Tri Mandiri Sakti, Bengkulu
}

\author{
*Correspondence: \\ Ruri Maiseptya Sari \\ Email: rury_maiseptyasari@yahoo.com \\ Address: STIKES Tri Mandiri Sakti Bengkulu, Jalan Hibrida Raya no.3, Bengkulu City
}

\begin{abstract}
Background: The school community's readiness to face disasters is still considered lacking in Indonesia. Schools as educational institutions are expected to provide an important role for disaster risk education, so students have the provision in dealing with disasters. Objective: This study aimed to identify the factors associated with the preparedness of high school students in dealing with the earthquake and tsunami disasters.

Method: This study is analytic survey with cross sectional design. The population in this study were all high school students in Bengkulu City in 2018/2019 academic year. Two stages cluster sampling method have been used in this study. The researcher randomly chooses one high school that will be used as a research location, SMAN 2 Bengkulu City were selected as the result, then the researcher randomly chooses again to determine which class will be the sample, class of XI was chosen with a total of 340 students who spread across 11 classes. The researchers calculated the sample size by using the Slovin formula with the results of 220 respondents. The samples were selected by using proportional random sampling technique, and chosen based on the number of students in each class. Data collection in this study used an instrument in the form of a questionnaire adopted from LIPI consists 65 questions about knowledge and 10 questions about disaster warning and 36 questions about preparedness. The collected data is then processed and analyzed using computer program software and the data were analyzed by using univariate, bivariate and multivariate logistic regression statistical tests

Result: The results of this study showed that preparedness of 220 respondents were obtained a mean of 23.57 with a standard deviation of 7.844 , knowledge were obtained a mean value of 46.69 with a standard deviation of 8.229 , attitudes were obtained a mean value of 60.01 with a standard deviation of 6.210, an emergency response plan were obtained a mean value of 14.95 with a standard deviation of 3.050 , and disaster warning were obtained a mean value of 7.19 with a standard deviation of 2.408. Factors related to student preparedness in dealing with disasters were included the level of knowledge $(p=0.020)$, attitude $(p=0.280)$, emergency response plan $(p=0.000)$, disaster warning $(p=0.000)$.

Conclusion: There is a relationship between the level of knowledge, and disaster warnings with disaster preparedness. The most dominant factor in disaster preparedness is disaster warnings.
\end{abstract}

Key words: Preparedness, knowledge, disaster warning.

\section{INTRODUCTION}

The territory of the Republic of Indonesia has geographical, geological, hydrological and demographic conditions that have high risk of natural disasters, whether caused by natural factors, non- natural factors or human factors that cause casualties, environmental damage, property losses and psychological impacts for victims. The position of Indonesia which is located on 3 (three) plates, namely Eurasian plates, Indo-Australian plates and Pacific 
plates has the potential to cause earthquakes and tsunami.

Disasters are a series of events that threaten and disrupt people's lives, whether caused by natural, non-natural factors, and human factors, which can lead to casualties, environmental damage, property losses, and psychological impacts (Undang Undang Republik Indonesia, 2007).

Over the past ten years, the increasing number of natural and non-natural disasters in the world is quite significant. Jumlah. The number of disasters in the world from 1991-2015 is fluctuating, which means that the number of disasters could not be estimated with certainty. Natural disasters that occur in the world are largely caused by the effects of climate change. Over the past several decades, the top five countries most frequently affected by disasters are China, The United States of America, Republic of Indonesia, Philippines and India. China was the country that experienced the highest number of natural disasters in 2005-2014.

Based on the Hazard Study Map ("Kajian Bahaya Puslitbang Geologi ESDM Bandung," 2006) it can be seen that the most vulnerable zone of earthquake in Bengkulu City is the area along the coast. These conditions should be accompanied by efforts to improve disaster preparedness to ensure that prompt and timely action is taken when a disaster occurs. Disaster preparedness refers to 5 parameters, developed by LIPI-UNESCO and accommodates 9 BNPB preparedness indicators, namely: knowledge, attitude towards disaster risk, policies and guidelines relating to preparedness to anticipate disasters, plans for disaster emergencies, disaster warning systems and resource mobilization.

The National Disaster Management Agency (BNPB), in the past more than 30 years (1982-2014) there were 13,729 disasters, which were dominated by floods and followed by landslides, strong winds, droughts and other disasters
(Kemendikbud, 2015). As for the results of the 2015 disaster risk assessment, there were five types of disasters with the highest exposure to fatalities: extreme weather (whirlwind) of 244 million people, drought of 228 million people, floods of 100 million people, earthquakes of 86 million people, and disasters landslides totaling 14 million (BNPB, 2011).

Bengkulu City based on its topography, placed at an elevation between 0-16 $\mathrm{m}$ above sea level with $70 \%$ flat topography and $30 \%$ small hilly and swampy. The west is a relatively narrow lowland, and is directly adjacent to the Indian Ocean, while the east is a plateau bordering the erosion-prone Bukit Barisan mountains (Profil Kesehatan Bengkulu, 2015).

Disaster preparedness is in the concerns of all individuals and all institutions, including educational institutions. Schools as educational institutions are expected to provide an important role for disaster risk education, so students have the provision in dealing with disasters. Knowledge about disaster is not yet fully known in depth by high school students, so that when a disaster occurs, it creates a sense of panic among students that can cause casualties. Bengkulu City has 10 senior high schools with a total number of 8,319 students, a large enough number of course also raises the risk of disasters that can occur among students in Bengkulu City.

Based on this background, the researcher is interested to study more deeply about the influence of knowledge, disaster warning and the preparedness of high school students in facing the earthquake and tsunami in Bengkulu City.

\section{METHODS}

Study Design

This research used analytic survey design with cross sectional design. 


\section{Setting}

This research was conducted at SMAN 2 Class of XI Bengkulu City on April 10 May 10, 2019.

\section{Research Subject}

The population in this study were all senior high school students in Bengkulu City in 2018/2019 school year. The two stages cluster sampling technique were used as sampling technique. The researcher randomly chooses one high school that will be used as a research location, the results are selected SMAN 2 Bengkulu City, then the researcher randomly chooses again to determine which class will be the research sample, class XI is chosen with a total of 340 students spread across 11 classes. Next the researchers calculated the sample size by using the Slovin formula with the results of 220 respondents. The samples were selected by using proportional random sampling technique, and was chosen based on the number of students in each class.

\section{Instruments}

The instrument or tool used in this study was a research questionnaire adopted from LIPI (Triyono, 2011). The questions in this study relate to personal factors that include knowledge, disaster warnings and student preparedness in the face of the earthquake and tsunami. The research questionnaire contained 65 questions about knowledge and 10 questions about disaster warning and 36 questions about preparedness that each respondent had to fill.

\section{Data Analysis}

The data were analyzed by using univariate, bivariate to determine the closeness of the relationship used chisquare statistical test $\left(\mathrm{X}^{2}\right)$ and multivariate. Multivariate analysis was analyzed by using logistic regression statistical tests.

\section{Ethical Consideration}

This study was approved by the Health Research Ethics Commission of the Ministry of Health Bengkulu with No. DM.01.04 / 101/3 / V / 2019.

\section{RESULTS}

The Overview of the Factors Related to the Preparedness in Facing the Earthquake and Tsunami Disaster

The analysis was conducted to obtain a picture of knowledge, early warning as an independent variable and Preparedness as the dependent variable. After the research is carried out, the following data were obtained:

Table 1. The Overview of the Factors Related to the Preparedness of SMAN 2 Students in Facing the Earthquake and Tsunami Disaster in Bengkulu City $(\mathrm{n}=$ 220).

\begin{tabular}{lccc}
\hline $\begin{array}{c}\text { Research } \\
\text { Variable }\end{array}$ & N & Mean & $\begin{array}{c}\text { Standard } \\
\text { Deviation }\end{array}$ \\
\hline Knowledge & 220 & 46.69 & 8.293 \\
$\begin{array}{l}\text { Disaster } \\
\text { Warning }\end{array}$ & 220 & 7.19 & 2.408 \\
Preparedness & 220 & 23.57 & 7.844 \\
\hline \multicolumn{2}{l}{ Source: Primary data of questionnaire, 2019 }
\end{tabular}

Based on table 1, it can be seen that the knowledge variable of 220 respondents in SMAN 2 class of XI obtained an average value (mean) of 46.69 with a standard deviation of 8.2293. The disaster warning variable from 220 respondents in SMAN 2 class of XI obtained an average value (mean) of 7.19 with a standard deviation of 2.408. The Preparedness of 220 respondents in SMAN 2 in class XI obtained an average value (mean) of 23.57 with a standard deviation of 7.844 . 
Correlation Test of Factors Related to The Preparedness in Facing the Earthquake and Tsunami Disaster

Bivariate analysis was performed to find out the interaction of two variables, and was used to assess the relationship between the independent variable (Knowledge and disaster warning) and dependent variable (Preparedness) of students in SMAN 2 Bengkulu City. The influence of knowledge and disaster warning to the preparedness of high school students in facing the earthquake and tsunami in Bengkulu City.

Table 2. Correlation Test of Factors Related to The Preparedness of SMAN 2 Students in Facing the Earthquake and Tsunami Disaster in Bengkulu City ( $\mathrm{n}=$ 220).

\begin{tabular}{lccc}
\hline Variable & N & $\begin{array}{c}\text { Spearman Rank } \\
\text { Correlation }\end{array}$ & $\boldsymbol{p}$-value \\
\hline Knowledge & 220 & 0.156 & 0.020 \\
$\begin{array}{l}\text { Disaster } \\
\text { Warning }\end{array}$ & 220 & 0.572 & 0.000 \\
\hline \multicolumn{3}{l}{ Source: Primary data of questionnaire, 2019 }
\end{tabular}

The table above illustrates the results of the correlation test Knowledge, and Disaster Warning with Preparedness using the Spearman Rank Correlation Test. From the table it is known that the result of Spearman Rank Correlation test for Knowledge with Preparedness is 0.156 with a p-value of 0.020 , Disaster Warning with Preparedness is 0.572 with a p-value of 0.000 . Because all $p$-value $<0.05$, it is said that there is a relationship between knowledge and disaster warning with preparedness.
Correlation of Multiple Knowledge and Disaster Warning with the Preparedness in Facing the Earthquake and Tsunami Disaster

Multiple correlation analysis is used to determine the degree or strength of the relationship between all independent variables (knowledge and disaster warnings) to the dependent variable (Preparedness) together.

Table 3. Correlation of Multiple Knowledge and Disaster Warning with the Preparedness of SMAN 2 Students in Facing the Earthquake and Tsunami Disaster in Bengkulu City $(\mathrm{n}=220)$.

\begin{tabular}{|c|c|}
\hline Variable & $\begin{array}{l}\text { Multiple } \\
\text { Correlation } \\
\text { Coefficient }\end{array}$ \\
\hline $\begin{array}{l}\text { Knowledge, Disaster } \\
\text { Warning with } \\
\text { Preparedness }\end{array}$ & 0.574 \\
\hline Source: Primary data of que & e, 2019 \\
\hline $\begin{array}{l}\text { Based on the tab } \\
\text { relationship betwee } \\
\text { disaster warning an } \\
\text { Correlation Value ( } \\
\text { disaster warning } \\
\text { 0.574. Because the } \\
\text { 0.6, the relationship } \\
\text { moderate category. }\end{array}$ & $\begin{array}{l}\text { ve illustrates } \\
\text { nowledge } \\
\text { paredness. } \\
\text { een knowled } \\
\text { reparedness } \\
\text { is between } 0 \\
\text { id to be of }\end{array}$ \\
\hline
\end{tabular}

Coefficient of Knowledge Determination and Disaster Warning with The Preparedness in Facing the Earthquake and Tsunami Disaster

The coefficient of determination $(R 2)$ basically measures how far the ability of the model in explaining the variation of the dependent variable. The coefficient of determination is between zero and one. A small $\mathrm{R}^{2}$ value means that the ability of the independent variables to run variations in the dependent variable is very limited. A value close to one means that the independent variables provide almost all 
the information needed to predict the variation of the dependent variable

Table 4. Coefficient of Knowledge Determination and Disaster Warning with The Preparedness of SMAN 2 Students in Facing the Earthquake and Tsunami Disaster in Bengkulu City $(\mathrm{n}=220)$.

\begin{tabular}{|c|c|}
\hline Variable & $\begin{array}{l}\text { Coefficient of } \\
\text { determination } \\
\qquad\left(\mathbf{R}^{2}\right)\end{array}$ \\
\hline $\begin{array}{l}\text { Knowledge, Disaster } \\
\text { Warning with } \\
\text { Preparedness }\end{array}$ & 0.330 \\
\hline
\end{tabular}

Based on the Table above the Determination Coefficient Value (R Square $=\mathrm{R}^{2}$ ) between Knowledge and Disaster Warning with Preparedness is 0.330. This means that the contribution of knowledge and disaster warning in influencing preparedness is $33.0 \%$, while $67.0 \%$ is influenced by other variables not examined in this study.

F-Test of Knowledge, disaster warning and the preparedness in Facing the Earthquake and Tsunami Disaster

The F statistical test basically shows whether all independent variables included in the model have a joint influence on the dependent variable.

Table 5. F-Test of Knowledge, disaster warning and the preparedness of SMAN 2 students in facing the earthquake and tsunami disaster in Bengkulu City $(\mathrm{n}=$ 220).

\begin{tabular}{lrcc}
\hline \multicolumn{1}{c}{ Variable } & F test & $\boldsymbol{p}$-value & Note \\
\hline Knowledge, & 35.460 & 0.000 & Significant \\
Disaster & & & \\
warning with & & & \\
preparedness & & & \\
\multicolumn{2}{l}{ Source: Primary data of questionnaire, 2019 } &
\end{tabular}

The table 5 showed the ANOVA test or $F$ test, that the calculated $F$ value was
35.460 with $p=0.000$. Because the $p$-value $<0.05$, the regression model can be used to predict preparedness.

Partial Test of the Relationship between Knowledge, Disaster Warning and the Preparedness in Facing the Earthquake and Tsunami Disaster

The statistical test $\mathrm{t}$ basically shows how far the relationship of one explanatory/ independent variable individually in explaining the variation of the dependent variable. By using the SPSS 21.0 for Windows program, the t-value obtained for the relationship of each independent variable is partially dependent on the dependent variable as follows.

Table 6. Partial Test of the Relationship between Knowledge, Disaster Warning and the Preparedness of SMAN 2 Students in Facing the Earthquake and Tsunami Disaster in Bengkulu City $(\mathrm{n}=220)$.

\begin{tabular}{lcccl}
\hline \multicolumn{1}{c}{ Variable } & B & t-count & $\boldsymbol{p}$-value & \multicolumn{1}{c}{ note } \\
\hline Knowledge & 0.047 & 0.832 & 0.407 & Not significant \\
Disaster & 1.446 & 7.146 & 0.000 & Significant \\
Warning & \multicolumn{5}{l}{} \\
\hline \multicolumn{2}{l}{ Source: Primary data of questionnaire, 2019 }
\end{tabular}

Table 6 showed that the value of $\mathrm{t}=$ 0.832 with a value of $p=0.407$, with the value of $p>0.05$, it is concluded that there is no statistically significant influence/ relationship between Knowledge and Preparedness. Table 6 showed that the value of $\mathrm{t}=7.146$ with a value of $p=0.000$, with the value of $p<0.05$, it is concluded that there is a statistically significant influence/ relationship between disaster warning and preparedness.

\section{DISCUSSION}

Description of Student Knowledge about Earthquake and Tsunami Disasters

Based on the results of research, it is known that knowledge variables of 220 respondents in SMAN 2 in class of XI obtained an average value (mean) of 46.69 with a standard deviation of 8.2293. 
The questionnaire was used to find out the knowledge of SMAN 2 students in class of XI, the data was distributed as many as 64 questions related to the earthquake and tsunami events, there are several questions answered incorrectly by students, included what is meant by natural disasters, what are the causes of earthquakes earth, what disasters that occur after the earthquake, what are the characteristics of a strong earthquake, what do you know or experience about tsunami and signs of a tsunami. This causes lack of knowledge among the students.

The results of this study are supported by LIPI, UNESCO (2006) which explained that the disaster preparedness policy is very important and a concrete effort to carry out disaster preparedness activities. Significant policies affect preparedness which included public education, emergency planning, disaster warning systems and resource mobilization, included funding, management organizations, critical facilities for disaster emergencies. The policies are listed in various forms, but it will be more meaningful if stated concretely in regulations such as: a statement $(\mathrm{SK})$ or regional regulation (perda) accompanied by a clear job description, so that the policy can be implemented optimally, then operational guidelines are needed.

This is in concordant with Hely's research (2014) that there is a significant relationship between knowledge and earthquake disaster preparedness at Bunda Thamrin General Hospital with a value of $\rho$ value $0.003<0.05$.

This study is similar with the study (Husna, 2011) where 63.3\% of respondents obtained a high level of knowledge about disaster preparedness. This result is concordant with the study by Devi A (2015), which showed that 58\% of respondents had sufficient knowledge about earthquake preparedness. The Result of this study was in consistent with study by
Taghizadeh and Khoshnaw (2017), only $33.7 \%$ students had a level of knowledge about disaster preparedness.

Description of Student Disaster Warning About Earthquake and Tsunami Disasters

Based on the results of research conducted among 220 respondents in SMAN 2 in class of XI, were found disaster warning variables with an average value (mean) of 7.19 and a standard deviation of 2.408 .

The questionnaire which distributed among students of SMAN 2 class of XI about disaster questions, were showed that for 10 questions, many students still do not know about tsunami-related signs, tools / signs to ask for tsunami assistance, what needs to be done, security alert, and disaster warning simulation.

The preparedness of the school community regarding the disaster warning system among students was found that respondents admitted, if there is earthquake and tsunami occurred, they would run to high ground (MPBI-UNESCO, 2007). This result was consistent with the research and preparation for the early warning system and early evacuation system sub-project in Jember Regency (YPM \& JICA, 2010), the final report presented that most respondents of the Panti Government apparatus stated that the government implementing unit, had a plan for early warning and evacuation activities under stress, and most Panti Government officials stated that the district government had a disaster warning system.

Description of Student Preparedness for Earthquake and Tsunami Disasters

Preparedness of 220 respondents in SMAN 2 in class of XI obtained an average value (mean) of 23.57 with a standard deviation of 7.844. The results also showed that some students were still confused about what to do when disaster strikes at school, where safe places to take cover and what objects or animals can be dangerous and 
should be avoided and what needs to be prepared when a disaster occurs.

According to Deni Hidayat, et al (2006) that early warning is a key factor that connects between the stages of disaster preparedness and emergency response. Preparedness is one of the important elements in pro-active disaster risk reduction control activities before a disaster occurs. The concept of preparedness is used more emphasis on the ability to take action to prepare for disaster emergencies quickly and accurately (LIPI, UNESCO, 2006). Launch of a campaign entitled "Disaster Risk Reduction Begins in Schools" to increase awareness of disaster reduction and ensure that lessons were taught at school.

This study was also strengthened a study by Sari (2014) on the description of students' preparedness for the earthquake and tsunami at the 2014 High School in Banda Aceh with a sample of 180 students. The results showed that the preparedness of students facing earthquake and tsunami disasters was in the fair category with a frequency of 114 students $(63.33 \%)$.

According to LIPI, UNESCO (2006) preparedness is actions that enable governments, organizations, communities, and individuals to be able to respond to a disaster situation quickly and accurately. Preparedness is one part of the disaster management process, especially earthquakes. Preparedness is an important element of pro-active disaster risk reduction control activities before a disaster occurs.

According to LIPI, UNESCO (2006) also said that elements that must be present to improve individual and household preparedness to anticipate natural disasters, are included knowledge, attitudes towards disaster risk, plans for disaster emergencies, disaster warning systems and the ability to mobilize resources power.
The Influence of Knowledge with the Preparedness of SMAN 2 Students in Facing the Earthquake and Tsunami Disaster in Bengkulu City

Table 6 showed there is a relationship between Knowledge and Preparedness obtained $\mathrm{t}$ value $=-0.832$ with $\mathrm{p}=0.407$, with the value of $p>0.05$, it can be said that there is no statistically significant influence/ relationship between Knowledge and Preparedness.

Knowledge of a person can usually influence attitudes and concerns to be prepared to anticipate disasters, especially for people who live in potential disaster areas. To increase disasters, the health staff in this case midwives must have an attitude and concern for disaster risk.

Knowledge and professional skills of health nurses and perceptions about the importance of health care services in disaster areas are needed to improve preparedness in the face of disasters. In addition to the importance of knowledge and skills, awareness is another thing that needed for the task in dealing with disasters.

A disaster mitigation activity is highly expected by all levels of society including the midwife profession, so that no one else does not know about the disaster and preparedness in facing disasters, such as the earthquake, tsunami and the risks that can be caused. Excessive concern at the community level does not arise anymore because they are ready with the knowledge that had been received from various parties or the government. Professionally, midwives are expected to have good level of knowledge on preparedness, in order to achieve good preparedness, midwives must have knowledge and competence in accordance with their authority obtained from formal and non-formal education as well as training on disaster preparedness.

Another consistent result in the case of disaster preparedness is a study from Syafrizal (2013) regarding the level of knowledge, preparedness and community 
participation in the construction of tsunami evacuation routes in the city of Padang which stated that communities with a level of preparedness for earthquakes and tsunamis are in the very prepared category.

The Effect of Disaster Warning with the Preparedness of SMAN 2 Students in Facing the Earthquake and Tsunami Disaster in Bengkulu City

From the table above we get the value of $t=7.146$ with a value of $p=0.000$, with the value of $p<0.05$, it can be said that there is a statistically significant influence between Disaster Warning on Preparedness. This result is supported by the results of a study on community team preparedness in dealing with the 2007 earthquake and tsunami disaster. The preparedness of the school community regarding the disaster warning system on students was found that respondents admitted, if there are earthquake and tsunami occurred, they would run to high ground (MPBI-UNESCO, 2007). "Description of Student Disaster Warning About Earthquake and Tsunami Disasters" This result was consistent with the research and preparation for the early warning system and early evacuation system subproject in Jember Regency (YPM \& JICA, 2010), the final report presented that most respondents of the Panti Government apparatus stated that the government implementing unit, had a plan for early warning and evacuation activities under stress, and most Panti Government officials stated that the district government had a disaster warning system.

This study in concordant with the study by Rachmalia, Astuti (2012), which the community picture was viewed from the tsunami warning system wich available in Teupah Barat Sub-district, Simeulue District. It was found that most respondents understood that the tsunami warning system would provide information about the possibility of a tsunami. This showed the preparedness of the tsunami warning system in the very ready category. A wellcoordinated disaster warning system will show the behavior of the people who understand the mitigation or evacuation process well, so that the community will be better prepared to face a tsunami disaster (BNPB, 2013). One of them is by increasing knowledge about the tsunami disaster warning system, which aims to anticipate the tsunami's impact early and to respond to the things that could have caused the tsunami disaster (Rachmalia, Astuti, 2012). It can be concluded that the disaster warning system for cadets is categorized as very ready. It is expected to anticipate the impact, that will be caused by the tsunami disaster and they are better prepared in the face of a tsunami disaster.

\section{CONCLUSION}

There is a significant relationship between knowledge, disaster warning and the preparedness of high school students in facing the earthquake and tsunami disaster in Bengkulu City with the results of the Spearman Preparedness Rank Correlation Test of 0.572 with a p-value of 0,000 . The most dominant factor with the preparedness of high school students in facing the earthquake and tsunami disaster in Bengkulu City is disaster warning with pvalue $=0,000$, significant on the $p$-value $<0.05$.

\section{SUGGESTIONS}

Preparedness has a very large positive influence; therefore, it is very important for schools to be able to conduct preparedness training in extracurricular health such as the teenage red cross and make SMAN 2 Bengkulu City one of the disaster preparedness schools in the city of Bengkulu. As the result of this research, extension media is very dominant in influencing student preparedness. Therefore, it is expected that students of SMAN 2 Bengkulu City can maintain and increase preparedness in the face of disasters. 


\section{ACKNOWLEDGMENT}

Acknowledments authors convey to all parties who have helped in writing this article, especially to the counselor and place of study.

\section{DECLARATION OF CONFLICTING INTEREST}

There are no conflicting interests involving this study.

\section{FUNDING}

This research was funded by the Directorate of Research and Community Service (DRPM) of the Ministry of Technology Research and Higher Education who has provided beginner lecturer research grants in 2019.

\section{AUTHOR CONTRIBUTION}

All authors contributed to the concept of study, design, collection data, analysis data, and for research.

\section{ORCID}

Ruri Maiseptya Sari

https://orcid.org/0000-0002-4877-8191.

Hanifah

https://orcid.org/0000-0003-4882-2962.

Vike Pebri Giena

https://orcid.org/0000-0003-0363-6840.

\section{REFERENCES}

American Cancer Society. (2012). Fatique BNPB. (2011). Penanggulangan Bencana. Retrieved from https://bnpb.go.id/uploads/migration /pubs/380.pdf

BNPB, B. dan U. (2013). Kesiapsiagaan menghadapi bencana Kota Padang 2013. Pilot Survei Pengetahuan, Sikap dan Perilaku. Jakarta: Pusdatin Humas BNPB.

Husna. (2011). Faktor-faktor yang Mempengaruhi Kesiapsiagaan Bencana Di RSUD ZA Banda Aceh. Idea Nursing Jurnal.
Devi A, S. D. (2015). Awareness on earthquake preparedness A key to safe life. International. Ournal of Nursing Research and Practice.

Kajian Bahaya Puslitbang Geologi ESDM Bandung. (2006).

LIPI, UNESCO, I. (2006). Pengembangan framework kajian kesiapsiagaan masyarakat dalam mengantisipasi bencana. Retrieved from http://www.coremap.or.id/i/.pdf

MPBI-UNESCO. (2007). Kajian Kesiapasiagaan Masyarakat Dalam Menghadapi Bencana Gempa Bumi Dan Tsunami Di Nias Selatan. Retrieved from http://unesdoc.unesco.org/ images/0015/001536/153617ind.pdf

Rachmalia, Astuti, P. (2012). Pengetahuan kesiapsiagaan tsunami pada masyarakat Teupah Barat, Kabupaten Simeulue. Idea Nursing Journal. Retrieved from http://www.jurnal.unsyiah.ac.id/INJ /article/ view/1589

Syafrizal. (2013). Tingkat pengetahuan, kesiapsiagaan dan partisipasi masyarakat dalam pembangunan jalur evakuasi tsunami di Kota Padang. Retrieved from http://ejournal.unp.ac.id/students/ index.php/pgeo/article/download/582/ 34

Taghizadeh A, Khoshnam, RM, K. A. (2017). Midwives' professional competency for preventing neonatal mortality in disasters. Health in Emergencies and Disasters Quarterly.

Triyono, T. (2011). Panduan Monitoring dan Evaluasi Sekolah Siaga Bencana. Jakarta: LIPI Press

Undang Undang Republik Indonesia. (2007). Penanggulangan Bencana. 
Cite This Article As: Sari, R.M., Hanifah, H., \& Giena, V.P. The Influence of Knowledge and Disaster Warning and The Preparation of High School Students in Facing Earthquake and Tsunami. Nurse and Health: Jurnal Keperawatan 2019; 8(2): 91-100. 